\title{
Intrapleural administration of tumour necrosis factor-alpha (TNF $\alpha$ ) in patients with mesothelioma: cytokine patterns and acute-phase protein response
}

\author{
T. C. Stam ${ }^{*}$, A. J. G. Swaak ${ }^{\dagger \ddagger}$, W. H. J. Kruit ${ }^{*}$, G. Stoter ${ }^{*}$ and A. M. M. Eggermont \\ "University Hospital Rotterdam, Daniel den Hoed Cancer Centre, Rotterdam, ${ }^{\dagger}$ Central Laboratory of the Netherlands \\ Red Cross Blood Transfusion Service and Laboratory for Experimental and Clinical Immunology, Amsterdam, and \\ ${ }^{\ddagger}$ Department of Rheumatology, Zuiderziekenhuis, Rotterdam, the Netherlands
}

\begin{abstract}
Background Tumour necrosis factor-alpha $(\mathrm{TNF} \alpha)$ has been found to be very effective in the isolated limb perfusion setting for advanced extremity tumours. In a phase I study of intrapleural administration of $\mathrm{TNF} \alpha 5$ patients were followed for inflammatory response patterns.

Patients and methods Malignant mesothelioma patients were treated with repeated intrapleural administration of $0 \cdot 1-0 \cdot 2 \mathrm{mg}$ recombinant $\mathrm{TNF} \alpha$. Samples of serum and pleural fluid were taken at different time-points before and after $\mathrm{TNF} \alpha$-administration. Levels of TNF $\alpha$, interleukin-6 (IL-6), interleukin-8 (IL-8), C-reactive protein (CRP) and secretory phospholipase $\mathrm{A}_{2}$ (sPLA $\mathrm{sP}_{2}$ ) were measured using enzyme-linked immunosorbent assays (ELISAs). Alpha 1-acid glycoprotein ( $\alpha 1-\mathrm{AG})$ was measured by nephelometry.

Results In pleural fluid TNF $\alpha$ and IL-8 reached peak levels, up to $50-700 \mathrm{ng} \mathrm{mL}^{-1}$ and 6$60 \mathrm{ng} \mathrm{mL}^{-1}$, respectively, $24 \mathrm{~h}$ after administration of TNF $\alpha$. IL-6 (peak levels up to $250 \mathrm{ng} \mathrm{mL}^{-1}$ ) and $\mathrm{sPLA}_{2}$ peaked after $48 \mathrm{~h}$. A slower and less dramatic pattern was observed for the levels of CRP and $\alpha 1$-AG. In serum no detectable levels of TNF $\alpha$ and no IL- 8 were observed, whereas serum levels of IL-6, sPLA 2 and CRP showed a clear increase after intrapleural administration of $\mathrm{TNF} \alpha$. Cytokines and acute-phase proteins showed the same pattern during subsequent cycles even up to 12 cycles. Tumour regression was not observed.

Conclusions In the setting of a phase I study of repetitive intrapleural administration of $\mathrm{TNF} \alpha$ in mesothelioma patients, we studied the characteristics of the inflammatory response. Intrapleural administration was followed by a clear inflammatory response locoregionally. In spite of $\mathrm{TNF} \alpha$ peak levels as high as $700 \mathrm{ng} \mathrm{mL}^{-1}$ systemic levels were never detectable. The secondary cytokine response led to very high intrapleural IL-6 and IL8 levels. Systemically IL-8 levels were never detectable whereas high IL-6 levels were induced systemically initially, with a decreased response to each intrapleural TNF $\alpha$ administration over time. The acute-phase response in contrast remained remarkably constant throughout the course of repeated intrapleural administrations of $\mathrm{TNF} \alpha$. Intrapleural administration of $\mathrm{TNF} \alpha$ is well tolerated but associated with inconsistent and rather moderate impact on production of pleural fluid. This can be achieved by other simpler and cheaper treatment, thus we see no justification for further studies.
\end{abstract}

Keywords Acute-phase response, cytokine response, intrapleural immunotherapy, mesothelioma, $\mathrm{TNF} \alpha$.

Eur F Clin Invest 2000; 30 (4): 336-343

\footnotetext{
Department of Surgical Oncology (T. C. Stam, A. M. M. Eggermont) and Medical Oncology (W. H. J. Kruit, G. Stoter), University Hospital Rotterdam, Daniel den Hoed Cancer Centre, Rotterdam; Department of Autoimmune Diseases, Central Laboratory of the Netherlands Red Cross Blood Transfusion Service and Laboratory for Experimental and Clinical Immunology, Amsterdam (A. J. G. Swaak); and Department of Rheumatology, Zuiderziekenhuis, Rotterdam (A. J. G. Swaak), the Netherlands.
}

Correspondence to: A. M. M. Eggermont, MD, PhD, Department of Surgical Oncology, Daniel den Hoed Cancer Centre, PO Box 5201, 3008 AE Rotterdam, the Netherlands. Tel.: +31 10 4391911; fax: +31 10 4391011; e-mail: eggermont@chih.azrnl.

Received 11 May 1999; accepted 28 December 1999

(C) 2000 Blackwell Science Ltd 


\section{Introduction}

Malignant mesothelioma is a tumour associated with exposure to asbestos [1]. Recent studies have indicated that the incidence of malignant mesothelioma with its long time between exposure and presentation of the disease will continue to rise in the future [2].

Malignant mesothelioma is a notoriously refractory tumour to all current treatments. Neither surgery [3] nor radiotherapy $[4,5]$ results in an increased survival. The median survival of mesothelioma is about 10 months $[4,6,7]$. Therefore various alternative approaches have been tested [8]. Pleural mesothelioma tends to stay locoregionally throughout most of its natural course [9]. This biological behaviour makes this disease amenable to locoregional administration of cytostatic agents or biologic agents such as interferon-gamma (IFN $\gamma$ ) [10], interferonalpha [11], IL-2 [12-14]. With intrapleural administration of IFN $\gamma$ or IL-2 antitumour responses have been recorded and it was speculated that $\mathrm{TNF} \alpha$ might be implicated in these antitumour effects. Thus we decided to explore intrapleural administration of $\mathrm{TNF} \alpha$, a cytokine that had failed systemic administration because of excessive toxicity $[15,16]$. Therefore the clinical use of $\mathrm{TNF} \alpha$ is restricted to locoregional application. It is already very successfully used in the treatment of irresectable sarcoma and melanoma $[17,18]$.

There are very few reports on intracavitary $\mathrm{TNF} \alpha$ in humans. TNF has been administered intraperitoneally in patients with advanced peritoneal carcinomatosis $[19,20]$. Regional toxicity (abdominal pain) instead of systemic toxicity was the dose-limiting factor in this setting. Intrapleural administration was studied in patients with malignant pleural effusion by Karck et al. [21]. Treatment with up to $200 \mu \mathrm{g} / \mathrm{m}^{2}$ weekly, led in 3 out of 6 patients to disappearance of effusion. Because of this preclinical and clinical data, we decided to perform a phase I study in patients with stage I-IIA malignant pleural mesothelioma with $\mathrm{rTNF} \alpha$ to study the clinical effect on pleural mesothelioma and evaluate the inflammatory response after this mode of administration.

We have previously shown [22] that leakage of $\mathrm{TNF} \alpha$ during isolated limb perfusion (ILP) caused an acute-phase response. This was demonstrated by an increase of IL- 6 directly after ILP until 2 days thereafter, followed by increase of CRP, $\alpha 1-\mathrm{AG}$ and $\alpha 1$-antitrypsin after 1 day, and decrease of negative acute-phase proteins albumin and transferrin during ILP till $6 \mathrm{~h}$ after ILP.

In the literature it is questioned whether the acute-phase protein response (APR) could be down regulated by a repeated stimulus [23]. Clinical studies have shown that in a number of chronic inflammatory diseases the APR is less than would be expected for the activity of inflammation [24-26]. In our patients a repeated stimulus is mimicked: at regular time intervals, 2 weeks, $\mathrm{TNF} \alpha$ is administered. This enables us to investigate whether repeated administration of $\mathrm{TNF} \alpha$ is still able to provoke an acute-phase response.

\section{Patients and methods}

\section{Patients}

Five patients with pleural mesothelioma in a phase I study were, respectively, sampled for evaluation of biologic response patterns. Demographical and clinical characteristics are summarised in Table 1. Staging and diagnosis of mesothelioma was based on computerised tomographic (CT) scan of the chest, thoracoscopic findings and histological examination of biopsy samples. According to Butchart's staging system [27] stage I is defined as tumour confined within the capsule of the parietal pleura, i.e. involving only ipsilateral pleura, lung, diaphragm and external surface of the pericardium within pleural reflection. Stage IIA is defined as mesothelioma invading chest wall or mediastinal tissues with or without lymphnode involvement ipsilaterally inside the chest.

Eligibility criteria required histologically confirmed pleural mesothelioma stage I-IIA, sufficient pleural effusion to insert an intrapleural catheter, no signs of loculation on the CT scan, no prior chemo-, radio- or immunotherapy, age $<76$ years, Karnofsky performance status $\geq 80 \%$, no cardiovascular disease, a white blood cell count $\geq 4 \cdot 0 \times 10^{9} 1^{-1}$, platelets $\geq 100 \times 10^{9} 1^{-1}$, serum bilirubin and creatinine levels within the institution's normal range, no active infection, no use of corticosteroids and obtained informed consent. The protocol was approved by the hospital's ethical committee.

Table 1 Patient characteristics and treatment response

\begin{tabular}{|c|c|c|c|c|c|c|}
\hline Patient no. & Age & Sex & Stage & $\begin{array}{l}\text { Treatment } \\
\text { after } 6 x\end{array}$ & $\begin{array}{l}\text { Response } \\
\text { after } 12 \times\end{array}$ & Response \\
\hline 1 & 63 & $\mathrm{M}$ & I & $1 \times 0 \cdot 1 \mathrm{mg}$ & - & - \\
\hline 2 & 65 & M & I & $12 \times 0 \cdot 1 \mathrm{mg}$ & SD & PD \\
\hline 3 & 63 & $M$ & IIA & $18 \times 0 \cdot 2 \mathrm{mg}$ & $\mathrm{SD}$ & SD-PD \\
\hline 4 & 65 & $\mathrm{M}$ & I & $6 \times 0.1 \mathrm{mg}$ & $\mathrm{PD}$ & - \\
\hline 5 & 57 & $\mathrm{M}$ & I & $6 \times 0 \cdot 1 \mathrm{mg}$ & PD & - \\
\hline
\end{tabular}




\section{Treatment schedule}

About 2 weeks before the first administration of $\mathrm{TNF} \alpha$ a Port-a-cath system was surgically inserted under general anaesthesia. The correct intrapleural position was examined radiographically and a technetium $-99 \mathrm{~m}$ colloid scan was made to evaluate the distribution of pleural fluid throughout the pleural cavity.

Recombinant human $\mathrm{TNF} \alpha$ (Boehringer Ingelheim, Germany) was administered as an intrapleural infusion, repeated every 14 days. Four patients were treated with a dose of $0 \cdot 1 \mathrm{mg}$, one patient with $0 \cdot 2 \mathrm{mg}$.

\section{Tumour response evaluation}

Response was evaluated after every 6 cycles using CT scan of the chest. Tumour response and toxicity were assessed according to the criteria of the World Health Organisation (1979) [28]. In case of measurable disease, complete response (CR) was defined as the disappearance of all known disease for at least 4 weeks; partial response (PR) as a decrease of $>50 \%$ in tumour size for at least 4 weeks; stable disease (SD) as a decrease of $<50 \%$ in tumour size. Progressive disease (PD) was defined as an increase of $>25 \%$ in the diameter of any lesion or the appearance of a new lesion.

\section{Immunomonitoring and cytokine- and acute-phase protein assays}

Both serum samples and pleural fluid were collected at 4 time-points during each cycle: $24 \mathrm{~h}$ before administration of $\mathrm{TNF} \alpha, 24 \mathrm{~h}$ and $48 \mathrm{~h}$ after administration and at day 8 . All samples were cryopreserved until testing.

Levels of $\mathrm{TNF} \alpha$, IL-6, IL-8, CRP and $\mathrm{sPLA}_{2}$ were measured using enzyme-linked immunosorbent assays (ELISA). Used antibodies were obtained from the Central Laboratory of the Blood Transfusion Service (Amsterdam, the Netherlands).

For measuring $\mathrm{TNF} \alpha$, as described previously [29], flatbottomed microtitre plates (Nunc, Kamstrup, Denmark) were coated overnight with purified monoclonal antibody (MAb) against TNF $\alpha$ (CLB-TNF/7). After washing serial dilutions of TNF-containing samples were added. Bound $\mathrm{TNF} \alpha$ was detected by biotinylated sheep anti-TNF $\alpha$. The detection limit of the assay was $5 \mathrm{pg} \mathrm{mL}^{-1}$. Healthy controls were below $5 \mathrm{pg} \mathrm{mL}^{-1}$.

The IL-6 specific ELISA was described previously [30]. A coat of CLB-IL-6/16 was applied overnight and bound IL-6 was detected by biotinylated affinity-purified polyclonal sheep anti-IL-6. Lower detection limit was $1 \mathrm{pg} \mathrm{mL}^{-1}$ and normal healthy control subjects were below $10 \mathrm{pg} \mathrm{mL}^{-1}$.

For IL-8 [31] a coat of CLB-IL-8/1 MAb was applied overnight and bound IL- 8 was detected by biotinylated affinity-purified polyclonal sheep anti-IL-8. The lower detection limit of this assay was $8 \mathrm{pg} \mathrm{mL}^{-1}$. Normal values were below $20 \mathrm{pg} \mathrm{mL}^{-1}$.
CRP levels were measured by a sandwich ELISA using polyclonal rabbit antihuman CRP Abs as catching Abs and biotinylated $\mathrm{MAb}$ anti-CRP (CLB anti-CRP-2) as a detecting $\mathrm{Ab}$ [32]. Results were referred to a standard (Behringwerke AG, Marburg, Germany) and expressed in $\mathrm{mgL}^{-1}$. Detection limit was $10 \mathrm{ngL}^{-1}$.

The ELISA used for measuring PLA $_{2}$ was described before [33]. Two different monoclonal antibodies against human sPLA $_{2}$ were used as coating and catching antibodies, respectively. The lower limit of detection was $0 \cdot 1 \mathrm{ng} \mathrm{mL}^{-1}$. Normal healthy volunteers were below $5 \mathrm{ng} \mathrm{mL}^{-1}$.

Levels of $\alpha 1$-acid glycoprotein were measured by means of a nephelometric assay. Antisera were obtained from the Central Laboratory of the Blood Transfusion Service (Amsterdam, the Netherlands). Normal values were $400-900 \mathrm{mg} \mathrm{L}^{-1}$.

\section{Results}

\section{Cytokine and acute-phase protein levels in pleural fluid}

Peak-levels (median with range) of cytokines and acutephase proteins of all patients are represented in Table 2 . In Figure 1 measurements of the first 6 cycles of patient 2 are depicted, the results of the other patients were comparable. After TNF-administration the concentration of $\mathrm{TNF} \alpha$ increased in $24 \mathrm{~h}$ to levels in the range of $50-$ $100 \mathrm{ng} \mathrm{mL}^{-1}$. After $48 \mathrm{~h}$ still some $\mathrm{TNF} \alpha$ was measurable (150-500 $\mathrm{pg} \mathrm{mL}^{-1}$ ). No $\mathrm{TNF} \alpha$ was measurable after 8 and 14 days. Before the first administration of TNF $\alpha$ IL6 was increased in all patients, values varying from 1200 to $80000 \mathrm{pg} \mathrm{mL}^{-1}$. It rose sharply to $100 \mathrm{ng} \mathrm{mL}^{-1}$ after $24 \mathrm{~h}$ and $250 \mathrm{ng} \mathrm{mL}^{-1}$ after $48 \mathrm{~h}$. After 8 days it declined to $30-80 \mathrm{ng} \mathrm{mL}^{-1}$, after 14 days levels were in the range of $15-33 \mathrm{ng} \mathrm{mL}^{-1}$. IL-8 started at $180-260 \mathrm{pg} \mathrm{mL}^{-1}$. It increased sharply during in the first $24 \mathrm{~h}$ to $2-12 \mathrm{ng} \mathrm{mL}^{-1}$, then it decreased to $0 \cdot 7-1 \cdot 0 \mathrm{ng} \mathrm{mL}^{-1}$ at $48 \mathrm{~h}$ and about $200 \mathrm{pg} \mathrm{mL}^{-1}$ after 8 days. After 14 days levels were around $150 \mathrm{pg} \mathrm{mL}^{-1}$. Levels of CRP increased during the first cycle from $3 \mathrm{mg} \mathrm{L}^{-1}$ at start to $60 \mathrm{mg} \mathrm{L}^{-1}$ after 8 days. Thereafter values remained constant around $60 \mathrm{mgL}^{-1} \cdot \mathrm{sPLA}_{2}$ increased during $48 \mathrm{~h}$ from around $5 \mathrm{ng} \mathrm{mL}^{-1}$ (3-9 $\mathrm{ng} \mathrm{mL}^{-1}$ after $24 \mathrm{~h}$ ) to $20-30 \mathrm{ng} \mathrm{mL}^{-1}$. It decreased slowly over the following 2 weeks. Levels of $\alpha 1-\mathrm{AG}$ remained constant around $1300 \mathrm{mgL}^{-1}$ after a slow rise from $700 \mathrm{mg} \mathrm{L}^{-1}$. The production of cytokines demonstrated the same pattern even after cycle 12 in patient 2 .

\section{Serum-cytokine and acute-phase protein levels}

In serum (Fig. 2, Table 2) no TNF $\alpha$ and no IL-8 was measurable in any patient. IL-6 could not be detected in 2 patients but rose sharply in the other 3, $24 \mathrm{~h}$ after 
Table 2 Peak values (median, range) of measured cytokines and acute-phase proteins in 5 patients

\begin{tabular}{|c|c|c|c|c|c|c|c|}
\hline \multicolumn{2}{|c|}{ Cytokine/ Acute-phase } & \multicolumn{3}{|l|}{ Serum } & \multicolumn{3}{|l|}{ Pleural fluid } \\
\hline Protein & Pat & Time & Median & Range & Time & Median & Range \\
\hline \multirow[t]{5}{*}{$\mathrm{TNF} \alpha \mathrm{pg} / \mathrm{mL}$} & $1 *$ & no peak & $<5$ & & $24 \mathrm{~h}$ & 30000 & \\
\hline & 2 & no peak & $<5$ & & $24 \mathrm{~h}$ & 51500 & $48000-118000$ \\
\hline & 3 & no peak & $<5$ & & $24 \mathrm{~h}$ & 678000 & $190000-1755000$ \\
\hline & 4 & no peak & $<5$ & & ND & & \\
\hline & 5 & no peak & $<5$ & & $24 \mathrm{~h}$ & 2156000 & $218000-4395000$ \\
\hline \multirow[t]{5}{*}{ IL-6 pg mL ${ }^{-1}$} & 1 & $24 \mathrm{~h}$ & 160 & & day 8 & 179000 & \\
\hline & 2 & $24 \mathrm{~h}$ & 173 & $121-279$ & $3 \times 48 \mathrm{~h}, 3 \times 24 \mathrm{~h}$ & 248000 & $187500-284000$ \\
\hline & 3 & no peak & $<1$ & & no peak & & $18000-142000$ \\
\hline & 4 & no peak & $<1$ & & $\mathrm{ND}$ & & \\
\hline & $5 \dagger$ & $24 \mathrm{~h}$ & 113 & $91-135$ & $24 \mathrm{~h}$ & 286000 & $148500-393000$ \\
\hline \multirow[t]{5}{*}{ IL-8 $\mathrm{pg} \mathrm{mL}^{-1}$} & 1 & no peak & $<8$ & & $24 \mathrm{~h}$ & 6300 & \\
\hline & 2 & no peak & $<8$ & & $24 \mathrm{~h}$ & 6000 & $2200-12400$ \\
\hline & 3 & no peak & $<8$ & & $24 \mathrm{~h}$ & 64400 & $51000-71000$ \\
\hline & 4 & no peak & $<8$ & & ND & & \\
\hline & 5 & no peak & $<8$ & & $24 \mathrm{~h}$ & 186500 & $3500-261000$ \\
\hline \multirow[t]{5}{*}{ CRP $\mathrm{mgl}^{-1}$} & 1 & $48 \mathrm{~h}$ & 499 & & day 14 & 83 & \\
\hline & 2 & $48 \mathrm{~h}$ & 501 & $385-618$ & no peak & & $3-69$ \\
\hline & 3 & no peak & & $70-223$ & no peak & & $31-81$ \\
\hline & 4 & $48 \mathrm{~h}$ & 276 & $216-446$ & ND & & \\
\hline & 5 & $48 \mathrm{~h}(2 \times 24 \mathrm{~h})$ & 409 & $327-875$ & day 8 & 88 & $71-198$ \\
\hline \multirow[t]{5}{*}{$\mathrm{SPLA}_{2} \mathrm{ng} / \mathrm{mL}$} & 1 & $48 \mathrm{~h}$ & 67 & & $48 \mathrm{~h}$ & 23 & \\
\hline & 2 & $48 \mathrm{~h}$ & 131 & $59-142$ & $48 \mathrm{~h}$ & 25 & $16-31$ \\
\hline & 3 & $48 \mathrm{~h}$ & 11 & $9-19$ & no peak & & $0 \cdot 1-7$ \\
\hline & 4 & $48 \mathrm{~h}$ & 47 & $28-78$ & ND & & \\
\hline & 5 & $48 \mathrm{~h}(3 \times 24 \mathrm{~h})$ & 87 & $65-174$ & $48 \mathrm{~h}$ & 21 & $17-64$ \\
\hline \multirow[t]{5}{*}{$\alpha 1-\mathrm{AG} \mathrm{mg}^{-1}$} & 1 & day 8 & 2420 & & ND & & \\
\hline & 2 & $3 \mathrm{xd} 8,3 \times 48 \mathrm{~h}$ & 2350 & $2090-2530$ & no peak & & $740-1560$ \\
\hline & 3 & no peak & & $1800-2610$ & $\mathrm{ND}$ & & \\
\hline & 4 & $48 \mathrm{~h}$ & 2440 & $2320-2630$ & ND & & \\
\hline & 5 & no peak & & $2100-2540$ & no peak & & $740-1620$ \\
\hline
\end{tabular}

* Only 1 cycle.

†IL-6 was measurable only during the first two cycles, thereafter it was under detection limit ND: not measured.

TNF-administration; values were in the range of $125-$ $275 \mathrm{pg} \mathrm{mL}^{-1}$. At $48 \mathrm{~h}$ it was still measurable in the first 4 cycles. In the course of treatment IL-6 levels gradually decreased. Before the first administration of $\mathrm{TNF} \alpha$, CRPlevels in serum were increased in all patients (31$300 \mathrm{mgL}^{-1}$ ). CRP-levels increased slowly from around $100 \mathrm{mgL}^{-1}$ after $24 \mathrm{~h}$ to $500 \mathrm{mg} \mathrm{L}^{-1}$ after $48 \mathrm{~h}$. After 8 days CRP was still measurable: values in the range of $100 \mathrm{mg} \mathrm{L}^{-1}$. After 14 days values were around $40 \mathrm{mg} \mathrm{L}^{-1}$. $\mathrm{sPLA}_{2}$ was increased after 24 and $48 \mathrm{~h}$ to about $30 \mathrm{ng} \mathrm{mL}^{-1}$ and $130 \mathrm{ng} \mathrm{mL}^{-1}$, respectively. After a few cycles $\mathrm{sPLA}_{2}$ was also measurable after 8 days: about $7 \mathrm{ng} \mathrm{mL}^{-1} . \alpha 1-\mathrm{AG}$ was raised before administration of $\mathrm{TNF} \alpha$ (1200$2000 \mathrm{mg} \mathrm{L}^{-1}$ ), it increased after $24 \mathrm{~h}$ after administration to about $2500 \mathrm{mg} \mathrm{L}^{-1}$ at day 8 . After 14 days it was around $2000 \mathrm{mg} \mathrm{L}^{-1}$.

\section{Toxicity and tumour response}

Five male patients were treated with intrapleural infusion of $\mathrm{TNF} \alpha$. Stage I patients were treated with $0 \cdot 1 \mathrm{mg}$ and one patient with stage IIA mesothelioma was treated with
$0 \cdot 2 \mathrm{mg}$. One patient received only one dose of $\operatorname{TNF} \alpha$ : Because of excessive pleural effusion, for which the patient needed drainage of pleural fluid, complicated by a haematothorax, further intrapleural TNF-administration could not be pursued. The other 4 patients were evaluable for toxicity and tumour response as they received a minimum of 6 doses up to 18 doses. Overall tolerance was quite good. All patients developed flu-like symptoms and mild fever $\left(38-39 \cdot 3^{\circ} \mathrm{C}\right)$ during $1-2$ days. Two patients had a short episode of nausea and vomiting. No grade III-IV toxicity according to the WHO-criteria [28] was observed. No hypotension or increase in heart rate was observed. Furthermore, intrapleural $\mathrm{TNF} \alpha$ had no effect on number of leukocytes and thrombocytes, kreatinin and liver functions.

None of the patients had a tumour response, only one patient showed stable disease during 36 weeks. Of note, once started with treatment none of the patients needed drainage of pleural fluid any more. In 2 patients dyspnea diminished obviously during treatment. Concerning the other 2 patients: in one patient dyspnea did not change and one patient did not have complaints of breathlessness. 
(a)

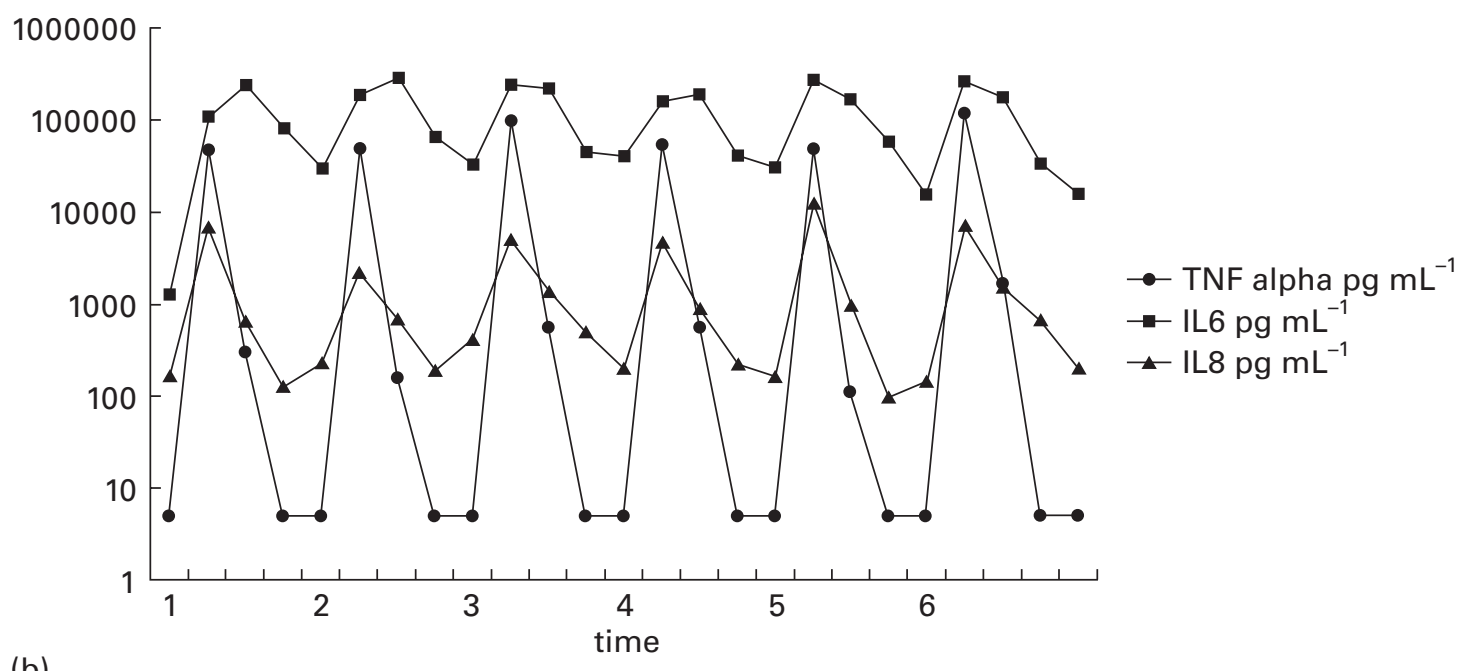

(b)

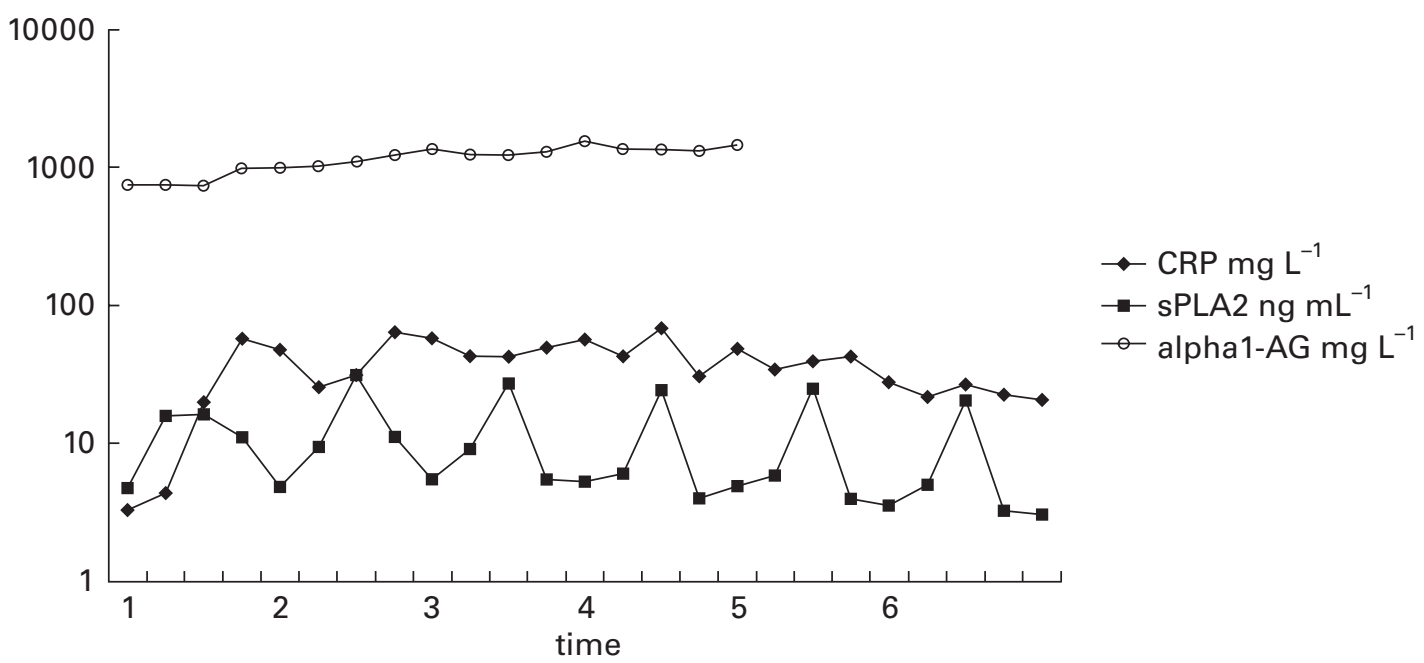

Figure 1 Cytokine (a) and acute-phase protein (b) profile in pleural fluid during the first 6 cycles of intrapleural TNFadministration in patient 2 . Time-points: $24 \mathrm{~h}$ before

\section{Discussion}

In the present study the biologic effects of intrapleural administration of $\mathrm{TNF} \alpha$ in patients with pleural mesothelioma was studied. The results of the cytokine measurements before administration of $\mathrm{TNF} \alpha$ showed signs of an ongoing inflammatory response. This was also observed by others [34,35]. Before administration of $\mathrm{TNF} \alpha$ intrapleural levels of IL-6, IL-8, CRP, sPLA ${ }_{2}$ and $\alpha 1-\mathrm{AG}$ were elevated. In serum we found increased levels of CRP and $\alpha 1$-AG. Our measurements correspond to the observations of Nakano et al. and Monti et al. The high intrapleural IL-6 levels, before the first administration of $\mathrm{TNF} \alpha$, appeared to be caused by production by the mesothelioma-cells. IL- 6 has been shown to be produced by mesothelioma-cells in vitro $[36,37]$. IL-6, produced in the pleural cavity, leaking to the systemic circulation, is administration of TNF $\alpha, 24 \mathrm{~h}$ after TNF-administration, $48 \mathrm{~h}$ after, and 8 days after. Day 14 is $24 \mathrm{~h}$ before the next gift of $\mathrm{TNF} \alpha$.

thought to be the responsible cytokine for the induction of the acute-phase response. The mechanism of the acutephase response has been investigated and described earlier, both in vitro $[38,39]$ and in vivo $[26,40,41]$.

Intrapleural administration of $\mathrm{TNF} \alpha$ resulted in clear IL-6, CRP, sPLA ${ }_{2}$ and $\alpha 1$-AG patterns in serum, with the noticeable exception for TNF $\alpha$ and IL-8, which never reached detectable levels systemically. This may be explained by soluble receptors for TNF $\alpha$ and IL-8. With respect to the IL-6 response in serum a significant increase with a peak after $48 \mathrm{~h}$ was observed after each TNFadministration. However the response diminished gradually in the course of time, most illustrative visible in patient 2 in which no detectable IL- 6 levels were observed when $\mathrm{TNF} \alpha$ had been administered more than 9 times. This points to an 'exhaustion' phenomenon or a gradual build-up of soluble IL-6 receptor levels. 
(a)

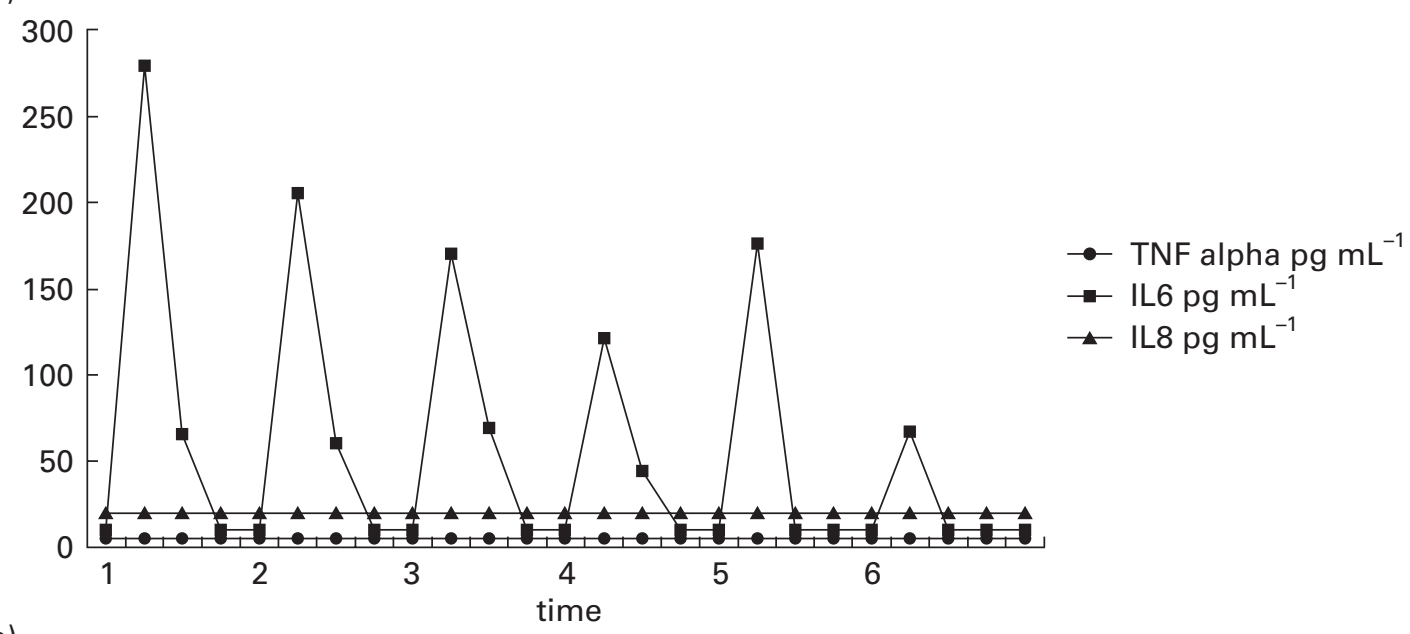

(b)

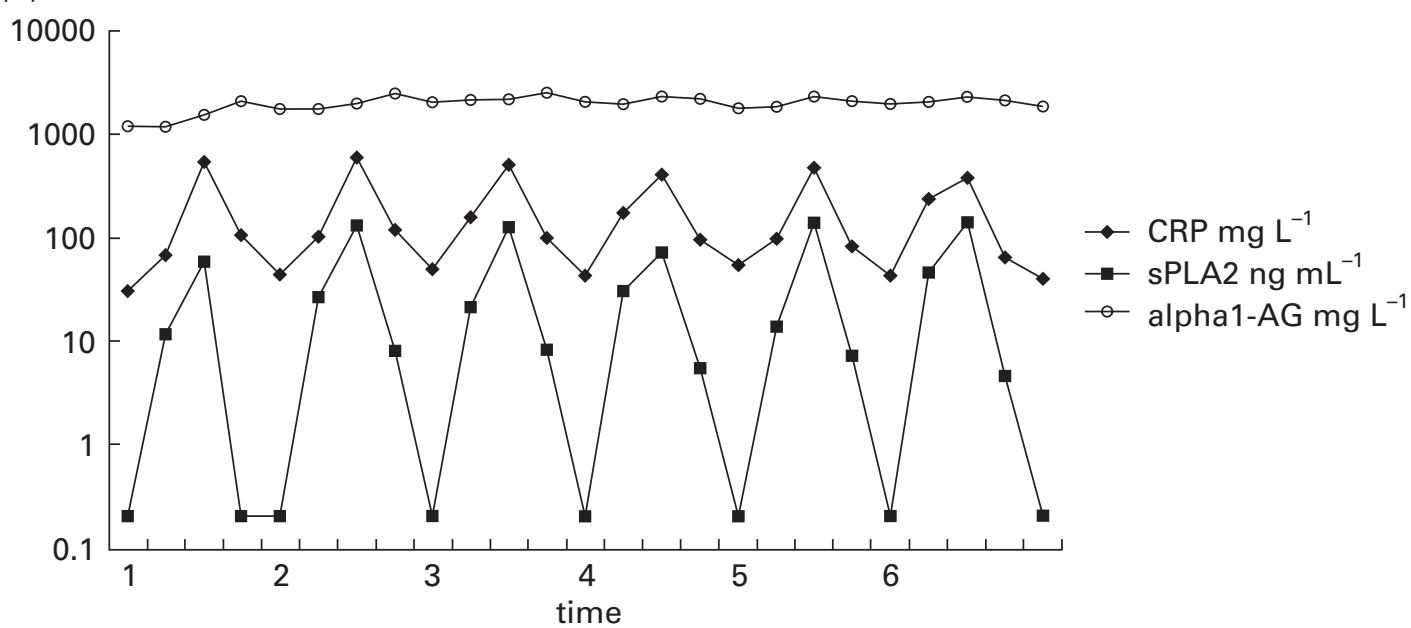

Figure 2 Cytokine (a) and acute-phase protein (b) profile in serum during the first 6 cycles of intrapleural administration of $\mathrm{TNF} \alpha$ in patient 2 . Time-points: $24 \mathrm{~h}$ before administration

However, the acute-phase response was not diminished. This may be explained by a direct stimulation of the acutephase response by $\mathrm{TNF} \alpha$ and IL-1 $[26,40] . \mathrm{TNF} \alpha$ and IL-1 are only able to stimulate the positive acute-phase proteins. So in our study (we only determined positive acute-phase proteins) we could not distinguish which cytokine had the most impact on the stimulation of the APR: IL- 6 or $\mathrm{TNF} \alpha / \mathrm{IL}-1$. In contrast with the studies mentioned above [24-26], we could not find a down-regulation of the APR, even though the acute-phase response was already activated before the first TNF-administration. Administration of $\mathrm{TNF} \alpha$ did increase the levels of the acute-phase proteins; this indicates that the APR was not maximally stimulated before the first TNF-administration. A possible explanation for the fact that we did not find a downregulation of the APR could be the relatively long treatment free period of 2 weeks between the consecutive administrations of $\mathrm{TNF} \alpha$.

$\mathrm{TNF} \alpha$ had no antitumour effect in these 4 mesotheliomapatients, but seemed to diminish pleural effusion. Reduction of $\mathrm{TNF} \alpha, 24 \mathrm{~h}$ after TNF-administration, $48 \mathrm{~h}$ after, and 8 days after. Day 14 is $24 \mathrm{~h}$ before the next gift of $\mathrm{TNF} \alpha$.

of pleural fluid was also described before [21,42]. The mechanism why TNF reduces pleural fluid is not quite clear. Most likely, fluid production by mesothelioma cells is reduced. Enhanced resorption of pleural fluid is less likely as this mechanism would be associated with higher systemic levels of $\mathrm{TNF} \alpha$ and other cytokines, which we did not observe.

In conclusion, intrapleural administration of $\mathrm{TNF} \alpha$ was followed by a clear inflammatory response locoregionally. In spite of $\mathrm{TNF} \alpha$ peak levels as high as $700 \mathrm{ng} \mathrm{mL}^{-1}$ systemic levels were never detectable. The secondary cytokine response led to very high intrapleural IL-6 and IL-8 levels. Systemically IL-8 levels were never detectable whereas high IL-6 levels were induced systemically initially, with a decreased response to each intrapleural $\mathrm{TNF} \alpha$ administration over time. The acute-phase response in contrast remained remarkably constant throughout the course of repetitive intrapleural administrations of $\mathrm{TNF} \alpha$. Intrapleural administration of $\mathrm{TNF} \alpha$ is well tolerated but associated with a rather moderate impact on production of 
pleural fluid. As this effect can be achieved by other simpler and cheaper treatment we see no justification for further studies.

\section{References}

1 Selikoff IJ, Churg J, Hammond FC. Relations between exposure to asbestos and mesothelioma. New Engl f Med 1965;272:560-5.

2 Peto J, Hodgson JT, Matthews FE, Jones JR. Continuing increase in mesothelioma mortality in Britain. Lancet 1995;345:535-9.

3 Rusch VW, Piantadosi S, Holmes EC. The role of extrapleural pneumonectomy in malignant pleural mesothelioma. A Lung Cancer Study Group Trial 7 Thorac Cardiovasc Surg 1991;102:1-9.

4 Alberts AS, Falkson G, Goedhals L, Vorobiof DA, Van der Merwe CA. Malignant pleural mesothelioma: a disease unaffected by current therapeutic manoeuvres. $\mathcal{F}$ Clin Oncol 1988;6:527-35.

5 Ball DL, Cruickshank DG. The treatment of malignant mesothelioma of the pleura: review of a 5-year experience with special reference to radiotherapy. Am $\mathcal{F}$ Clin Oncol 1990;13:4-9.

6 Curran D, Sahmoud T, Therasse P, Van Meerbeeck JP, Postmus PE, Giaccone G. Prognostic factors in patients with pleural mesothelioma: The European Organization for Research and Treatment of Cancer Experience. $\mathcal{F}$ Clin Oncol 1998;16:145-52.

7 Brenner J, Sordillo PP, Magill GB, Golbey RB. Malignant mesothelioma of the pleura, review of 123 patients. Cancer 1982;49:2431-5.

8 Fitzpatrick DR, Manning LS, Musk AW, Robinson BWS, Bielefeldt-Ohmann H. Potential for cytokine therapy of malignant mesothelioma. Cancer Treatment Reviews 1995;21:273-88.

9 Antman KH, Blum RH, Greenberber JS et al. Multimodality therapy for malignant mesothelioma on a study of natural history. Am f Med 1980;68:356-61.

10 Boutin C, Viallat JR, Van Zandwijk N, Douillard JT, Paillard C, Guerin JC et al. Activity of intrapleural gammainterferon in malignant mesothelioma. Cancer 1991;67: 2033-7.

11 Markowitz A, Thielvoldt D, Yeomans A, Rubenstein E, Escalante C, Freimann K et al. Beneficial effects of intracavitary interferon- $\alpha 2 \mathrm{~b}$ (IFN): a phase I study in patients with ascites or pleural effusion. Proc Am Assoc Clin Oncol 1992;11:258

12 Yasumoto K, Miyazaki K, Nagashima et al. Induction of lymphokine-activated killer cells by intrapleural instillations of recombinant interleukin-2 in patients with malignant pleurisy due to lung cancer. Cancer Res 1987;47:2184-7.

13 Eggermont AMM, Goey SH, Slingerland R, Jansen RLH, Oosterom R, Bolhuis RLH et al. Clinical and immunological evaluation of intrapleural administration of IL-2 in malignant pleural mesothelioma. A Phase I-II Study Proc Am Assoc Cancer Res 1991;32:206.

14 Goey SH, Eggermont AMM, Punt CJA, Slingerland R, Gratama JW, Oosterom $\mathrm{R}$ et al. Intrapleural administration of interleukin 2 in pleural mesothelioma: a phase I-II study. $\mathrm{Br} \mathcal{F}$ Cancer 1995;72:1283-8.
15 Feinberg B, Kurzrock R, Talpaz M, Blick M, Saks S, Guterman JM. A phase I trial of intravenously administered recombinant tumour necrosis factor alpha in cancer patients. f Clin Oncol 1988;6:1328-34.

16 Spriggs DR, Sherman ML, Michie $\mathrm{H}$ et al. Recombinant human tumour necrosis factor administered as a $24 \mathrm{~h}$ intravenous infusion. A phase I and pharmacologic study. $\mathcal{F}$ Natl Cancer Inst 1988;80:1039-44.

17 Eggermont AMM, Schraffordt Koops H, Liénard D, Kroon BBR, Van Geel AN, Hoekstra HJ et al. Isolated limb perfusion with high dose tumour necrosis factor- $\alpha$ in combination with IFN $\gamma$ and melphalan for irresectable extremity soft tissue sarcomas: a multicenter trial. $\mathcal{f}$ Clin Oncol 1996;14:2653-65.

18 Liénard D, Eggermont AMM, Schraffordt Koops H, Kroon BBR, Rosenkaimer F, Autier P et al. Isolated perfusion of the limb with high dose tumour necrosis factor-alpha $(\mathrm{TNF} \alpha)$ and interferon-gamma (IFN $\gamma)$ and melphalan for melanoma stage III. Results of a multi-center pilot study. Melanoma Res 1994;4:21-6.

19 Reichman B, Markman M, Ianotti N et al. Phase I trial of intraperitoneal recombinant tumour necrosis factor. Proc Am Assoc Clin Oncol 1989;8:64 (Abstract).

20 Hardy J, Jones A, Gore ME, Viner C, Selby B, Wiltshaw E. Treatment of advanced ovarian cancer with intraperitoneal tumour necrosis factor. Eur $\mathcal{F}$ Cancer 1990;26:771-2.

21 Karck U, Meerpohl HG, Pfleiderer A et al. TNF therapy of ascites and pleural effusion due to gynaecological carcinomas. f Cancer Res Clin Oncol 1990;116:328 (Abstract).

22 Swaak AJG, Liénard D, Schraffordt Koops H, Lejeune FJ, Eggermont AMM. Effects of recombinant tumour necrosis factor $(\mathrm{rTNF}-\alpha)$ in cancer. Observation on the acute-phase protein reaction and immunoglobulin synthesis after high dose recombinant $\mathrm{TNF}-\alpha$ administration in isolated limb perfusions in cancer patients. Eur F Clin Invest 1993;23:8128.

23 Todd NJ, Whicher JT, Westacott C, Gilbert A. The acute-phase protein response in mice does not show tolerance to recurrent sterile inflammation. Clin Chim Acta 1990;189:47-54.

24 Whicher JT, Bell AM, Martin MFR, Marshall LA, Dieppe PA. Prostaglandins cause an increase in serum acutephase proteins in man, which is diminished in systemic sclerosis. Clin Sci 1984;66:165-71.

25 Yorston D, Whicher JT, Chambers R, Klouda P, Easty D. The acute-phase response in acute anterior uveitis. Trans Ophthalmol Soc UK 1985;104:166-70.

26 Biró L, Domján Gy Falus A et al. Cytokine regulation of the acute-phase protein levels in multiple myeloma. Eur 7 Clin Invest 1998;28:679-86.

27 Butchart EG, Ashcroft T, Barsley WC, Holden MP. Pleuropneumonectomy in the management of diffuse malignant mesothelioma of the pleura. Thorax 1976;31:15-24.

28 World Health Organisation. Handbook for Reporting Results of Cancer Treatment. WHO Offset Publication no. 48. Geneva, Switzerland:World Health Organisation; 1979.

29 Van Kooten C, Rensink I, Pascal-Salcedo D, Van Oers R, Aarden LA. Monokine-production by human T-cells; IL- $1 \alpha$ production restricted to memory T-cells. $\mathcal{F}$ Immunol 1991;146:2654-8.

30 Helle M, Boeije L, De Groot ER, De Vos A, Aarden LA. Sensitive ELISA for interleukin 6. Detection of IL-6 in biological fluids and sera. F Immunol Methods 1991;138:42-56.

31 Verbrugh CA, Hart MH, Aarden LA, Swaak AJG. Interleukin-8 
(IL-8) in synovial fluid of rheumatoid and nonrheumatoid joint effusions. Clin Rheumatol 1993;12:494-6.

32 Wolbink GJ, Brouwer MC, Buysmann S, Ten Berge IJM, Hack CE. CRP-mediated activation of complement in vivo. Assessment by measuring circulating complement-C-reactive protein complexes. F Immunol 1996;157:473-9.

33 Wolbink GJ, Schalkwijk C, Baars JW, Wagstaff J, Van den Bosch H, Hack CE. Therapy with interleukin-2 induces the systemic release of phospholipase- $\mathrm{A}_{2}$. Cancer Immunol Immunother 1995;41:287-92.

34 Nakano T, Chahinian AP, Shinjo M, Tonomura A, Miyake $\mathrm{M}$, Togawa $\mathrm{N}$ et al. Interleukin 6 and its relationship to clinical parameters in patients with malignant pleural mesothelioma. Br f Cancer 1998;77:907-12.

35 Monti G, Jaurand MC, Monnet I et al. Intrapleural production of interleukin 6 during mesothelioma and its modulation by $\gamma$-interferon treatment. Cancer Res 1994;54:441923.

36 Schmitter D, Lauber B, Fagg B, Stahel RA. Heamatopoietic growth factors secreted by seven human pleural mesothelioma cell lines: interleukin-6 production as a common feature. Int $\mathcal{F}$ Cancer 1992;51:296-301.

37 Bielefeldt-Ohmann H, Marzo AL, Himbeck RP, Jarnicki AG, Robinson BW, Fitzpatrick DR. Interleukin-6 involvement in mesothelioma pathobiology: inhibition by interferon alpha immunotherapy. Cancer Immunol Immunother 1995;40:241-50.

38 Castell JV, Gomez-Lechon MJ, David M, Fabra R, Trullenque R, Heinrich PC. Acute-phase response of human hepatocytes: regulation of acute-phase protein synthesis by interleukin-6. Hepatology 1990;12:1179-86.

39 Knolle P, Lohr H, Treichel U, Dienes HP, Lohse A, Schlaack J et al. Parenchymal and nonparenchymal liver cells and their interaction in the local immune response. $Z$ Gastroenterol 1995;33:613-20.

40 Pullicino EA, Carli F, Poole S, Rafferty B, Malik ST, Elia M. The relationship between the circulating concentrations of interleukin 6 (IL-6, tumour necrosis factor (TNF) and the acute-phase response to elective surgery and accidental injury. Lymphokine Res 1990;9:231-8.

41 Evans CA, Jellis J, Hughes SP, Remick DG, Friedland JS. Tumour necrosis factor-alpha, interleukin-6 and interleukin- 8 secretion and the acute-phase response in patients with bacterial and tuberculous osteomyelitis. F Infect Dis 1998;177:1582-7.

42 Rauthe G, Sistermanns J. Recombinant tumour necrosis factor in the local therapy of malignant pleural effusion. Eur $\mathcal{F}$ Cancer 1997;33:226-31. 